discussion papers FÜR SOZIALFORSCHUNG

SOCIAL SCIENCE RESEARCH CENTER BERLIN

FS IV $02-25$

Strategic Trade Policy and the Home Bias in Firm Ownership Structure

Steffen Huck*

Kai A. Konrad**

* University College London and ELSE

** Wissenschaftszentrum Berlin für Sozialforschung

December 2002

ISSN Nr. 0722 - 6748

Forschungsschwerpunkt

Markt und politische Ökonomie

Research Area

Markets and Political Economy 
Zitierweise/Citation:

Steffen Huck, Kai A. Konrad, Strategic Trade Policy and the Home Bias in Firm Ownership Structure, Discussion Paper FS IV 02-25, Wissenschaftszentrum Berlin, 2002.

Wissenschaftszentrum Berlin für Sozialforschung gGmbH, Reichpietschufer 50, 10785 Berlin, Tel. (030) 25491 - 0 Internet: www.wz-berlin.de 


\section{ABSTRACT \\ Strategic Trade Policy and the Home Bias in Firm Ownership Structure}

by Steffen Huck and Kai A. Konrad

In this note we consider the preferences of a profit maximizing firm for international ownership in a world in which firms compete in an international Cournot oligopoly, and in which countries use strategic trade policy. We find that firms prefer national ownership and show that full indigenisation occurs in the equilibrium.

Keywords: Strategic trade, international ownership, Cournot oligopoly, home bias JEL classification numbers: D43, D44, F12, L11, L13

\section{ZUSAMMENFASSUNG}

\section{Strategische Außenhandelspolitik und der Home Bias in der Unternehmens- beteiligungsstruktur}

Die internationalen Beteiligungsverhältnisse eines Unternehmens bestimmen die internationale Verteilung der Profite des Unternehmens. Die Beteiligungsverhältnisse beeinflussen deshalb die Anreize für nationale Subventionspolitik im Rahmen strategischer Außenhandelspolitik. In der vorliegenden Arbeit wird untersucht, welche internationalen Beteiligungsverhältnisse ein gewinnmaximierendes Unternehmen bevorzugen würde, könnte es die internationale Zusammensetzung seiner Eigner wählen. Es wird gezeigt, dass in einem internationalen Cournot-Oligopol ein Gleichgewicht der Beteiligungsverhältnisse existiert, in dem jedes Unternehmen nur Personen als Eigner hat, die in dem gleichen Land ansässig sind, in dem sich der Sitz des betreffenden Unternehmens befindet. Das Ergebnis leistet einen Beitrag zur Erklärung des empirisch wohlbekannten Sachverhalts, wonach die internationale Portfoliodiversifikation von Investoren weitaus geringer ist, als es einer optimalen Risikostreuung entsprechen würde.

The first author acknowledges financial support from the Economic and Social Research Council (UK) via the Centre for Economic Learning and Social Evolution (ELSE). 


\section{Introduction}

In this note we consider the preferences of a profit maximizing firm for international ownership in a world in which firms compete in an international Cournot oligopoly, and in which countries use strategic trade policy. We find that firms prefer national ownership and show that full indigenisation occurs in equilibrium.

It has been noted earlier that internationally dispersed firm ownership matters for countries' incentives vis-a-vis firms in their own country. Barros and Cabral (1994) study merger in an international framework showing that foreign ownership should change a regulator's decisions if the regulator cares about national welfare. ${ }^{1}$ In the context of strategic trade policy, Dick (1993) and Welzel (1995) study two-firm-two-country models and show that countries' incentives to subsidize home firms may decrease in the presence of international ownership. Dick supports this theoretical result also by data from US industries. ${ }^{2}$

We endogenize the ownership structure of firms if this structure is chosen with the aim of maximizing the firm's profit and allow for the general case of $n$ firms in $n$ countries. Firms maximize profits and choose the international composition of their shareholders. Our main result is that fully national ownership is an equilibrium phenomenon. This finding may con-

\footnotetext{
${ }^{1}$ Similarly, Konrad and Lommerud (2001) show that a foreign investor may protect a larger share of the returns of foreign direct investment from confiscation by an indigenisation strategy. Indigenisation changes the host country's weights regarding the redistribution benefits and the production efficiency cost of extortionary taxation.

${ }^{2}$ Further related work includes Feeney and Hillman (2001) who study how strategic trade policy can change as a result of privatization of firms when equity is internationally tradeable.
} 
tribute to explaining the puzzle of strong and robust home country biases as documented, for example, in Adler and Dumas (1983), French and Poterba (1991) and Tesar and Werner (1995).

Our result does not follow trivially since an increase in the share of international owners has countervailing effects. It is not clear which effect dominates. Let us assume that all firms are fully nationally owned and that one firm, say firm A in country A deviates from that by raising some capital in country B. This will have the following effects.

- The incentives for country B to subsidize their own firms are reduced due to cannibalization. C.p., this is of benefit for firm A.

- The incentives for country A to subsidize firm A are reduced because some of firm A's profits now flow into country B. C.p., this harms firm A.

We are not able to determine which effects are dominating in general, but we show that starting from full indigenization, the negative effect of going international overpowers the advantage that is caused by the first effect. Hence, full national ownership is an equilibrium phenomenen. This, however, does not rule out that there are (potentially fully mixed) equilibria where firms become multinationals.

The assumption that firms can influence the international composition of their shareholders may need some justification. For private firms this is a natural assumption. Here existing (domestic) owners as well as the management do have control over the choice of new investors. Moreover, as it will turn out that foreign ownership reduces equilibrium profits, new investors' willingness to pay for a share of the company falls short of the value this share has if the firm continues to be owned by domestic investors. For public 
firms the assumption is harder to justify. Particularly, portfolio investors from abroad cannot be assumed to internalize the reduction of the firm's profits that results from international ownership, if their investment share is small. However, if the firm is controlled by a group of large shareholders, given the results developed here, these may have a common interest that none of them sells a block of shares to a foreign investor. More precisely, domestic shareholders and investors should be willing to pay a premium above the willingness-to-pay of a foreign investor because foreign ownership will reduce the market value of the firm. Also, it seems reasonable to assume that management have some sort of control when new capital is raised, for example, by the type of investor relations policy chosen, or the choice of accounting standards (national norms or US norms), and related to this, by the choice of the stock exchange at which the firm is listed.

Finally, in some cases our results might also give reason for public firms to go private again, a move that has gained some popularity in Europe. ${ }^{3}$

\section{International ownership and strategic trade}

We consider a symmetric situation using the standard strategic trade policy framework by Brander and Spencer (1985) but with $n$ firms in $n$ countries, firm $i$ being located in country $i$. Up to the point where we depart, the framework is well known and can be reviewed briefly. Firms produce quantities $x^{i}$ of a homogenous good which is exported to some other country that behaves passively with respect to its imports. For ease of notation, we assume linear demand and cost, the benchmark case for most oligopoly models. Without loss of generality we normalize marginal costs to zero and inverse demand to

\footnotetext{
${ }^{3}$ See, for example, Time Magazine from October 23, 2000 (Vol. 156).
} 
$p(X)=1-X$ with $X=\sum_{i} x^{i}$. Accordingly, firm $i$ 's profit is

$$
\pi^{i}=x^{i}\left(1-X+s_{i}\right)
$$

where $s_{i}$ is the subsidy paid to firm $i$ and chosen by government $i$ in order to maximize national welfare. The countries first choose their subsidies simultaneously, and once these are given and observed by everyone, the firms choose their quantities. For given subsidies we obtain

$$
x^{i *}=\frac{1-S}{n+1}+s_{i}
$$

with $S=\sum_{j} s_{j}$. Hence,

$$
\pi^{i *}=\left(\frac{1-S}{n+1}+s_{i}\right)^{2}
$$

Anticipating (2), countries choose subsidies. Country $j$ 's welfare is given by a weighted sum of the profits of those firms that are at least partly owned by citizens in country $j$ minus the subsidies paid to firm $j$. Using (2) we can write welfare as

$$
W_{j}=\sum_{i} \alpha_{j}^{i}\left(\frac{1-S}{n+1}+s_{i}\right)^{2}-s_{j}\left(\frac{1-S}{n+1}+s_{j}\right)
$$

where $\alpha_{j}^{i}$ is the share of firm $i$ owned by citizens of country $j$. Differentiating (4) with respect to $s_{j}$ we derive country $j$ 's first-order condition as

$$
\sum_{i} \frac{2 \alpha_{j}^{i}}{n+1}\left(\frac{1-S}{n+1}+s_{i}\right)+\left(1-2 \alpha_{j}^{j}\right) \frac{1-S}{n+1}=\left(2 \alpha_{j}^{j}-\frac{2 n+1}{n+1}\right) s_{j}
$$

For the case of pure national ownership everywhere, i.e. if all $\alpha_{j}^{j}=1$, we get $\widetilde{s}_{j}=\frac{n-1}{1+n^{2}}$, the generalized version of the well-known Brander and Spencer result. In that case, firm $i$ 's profits are given by $\widetilde{\pi}_{i}=\frac{n^{2}}{\left(1+n^{2}\right)^{2}}$.

The question arises whether national ownership is an equilibrium in a larger game where firms can first choose the international composition of 
equity holders before governments choose their subsidies, i.e., where a firm's strategy is the vector $\alpha^{i}=\left(\alpha_{1}^{i}, \ldots, \alpha_{n}^{i}\right)$ with $\sum_{j} \alpha_{j}^{i}=1$. To answer this question we first analyse the subsidy-setting subgame that countries play when all firms but one are fully indigenised, i.e., when $\alpha_{h}^{h}=1$ for all $h$ except $i$. In that case, the first order condition (5) for a country $h \neq i$ becomes

$$
\begin{aligned}
& \frac{2 \alpha_{h}^{i}}{n+1}\left(\frac{1-S}{n+1}+s_{i}\right)+\frac{2}{n+1}\left(\frac{1-S}{n+1}+s_{h}\right)+(1-2) \frac{1-S}{n+1} \\
= & \left(2-\frac{2 n+1}{n+1}\right) s_{h}
\end{aligned}
$$

while the first-order condition for country $i$ which hosts and subsidizes the internationally owned firm $i$ becomes

$$
\begin{aligned}
& \frac{2\left(1-\sum_{h \neq i} \alpha_{h}^{i}\right)}{n+1}\left(\frac{1-S}{n+1}+s_{i}\right)+\left(1-2\left(1-\sum_{h \neq i} \alpha_{h}^{i}\right)\right) \frac{1-S}{n+1} \\
= & \left(2\left(1-\sum_{h \neq i} \alpha_{h}^{i}\right)-\frac{2 n+1}{n+1}\right) s_{i}
\end{aligned}
$$

Solving the simultaneous equations (see the appendix) shows that the equilibrium subsidies depend only the total amount of capital firm $i$ seeks abroad. So, let $\varepsilon=\sum_{h \neq i} \alpha_{h}^{i}$. With this we get

$$
s_{i}^{*}=\frac{n-1-2 \varepsilon n}{2 \varepsilon n^{3}-2 \varepsilon n^{2}+n^{2}+1}
$$

and

$$
S^{*}=n \frac{2 \varepsilon n^{2}+n-4 \varepsilon n-1-2 \varepsilon}{2 \varepsilon n^{3}-2 \varepsilon n^{2}+n^{2}+1} .
$$

Substituting into (3) we can now write firm $i$ 's profit as a function of $\varepsilon$, namely as $\pi^{i}(\varepsilon)=\left(\frac{n}{2 \varepsilon n^{3}-2 \varepsilon n^{2}+n^{2}+1}\right)^{2}$. Taking the first derivative of this expression we find that

$$
\frac{d \pi^{i}(\varepsilon)}{d \varepsilon}=\frac{-4 n^{4}(n-1)}{\left(2 \varepsilon n^{3}-2 \varepsilon n^{2}+n^{2}+1\right)^{3}}<0 .
$$

Hence, it does not pay for firm $i$ to deviate from pure national ownership. 
Proposition 1 Pure national ownership (full indigenisation) is an equilibrium.

\section{Discussion}

In this paper we analyzed the relationship between international ownership and equilibrium profits for firms which compete in an international oligopoly in which countries use strategic trade policy. We show for the linear benchmark case that firms maximize their profits if they preserve national ownership.

Intuitively, internationally dispersed ownership reduces the subsidy a firm receives from its home country. This lowers the firm's profits. However, this effect is counteracted as international diversification of equity also reduces the other countries' subsidies to their own firms. We show that the direct effects of reduced subsidies in the home country dominates the beneficial effects of reduced subsidies to the firms in all other countries. Hence, fully domestic ownership of all firms occurs in the equilibrium.

The analysis highlights a strategic reason why firms prefer national ownership. Several simplifying restrictions have been made to make the analysis tractable, e.g., linear demand, constant marginal cost, complete and perfect information etc. Deviations from these assumptions may in some cases generate effects that add or substract to the benefit of national ownership but will typically not make the effect disappear. Two of these assumptions are particularly worthwhile to be discussed briefly.

One potentially restrictive assumption in our analysis is the symmetry of firms. This assumption reduces the analysis of $n$ players essentially to the two-players case, as each player cares only about the aggregate behavior of 
all other players. To check robustness, we therefore analysed the case of two countries with two firms and cost asymmetries, where cost asymmetries map firm size in a Cournot framework. Let the two firms differ in their constant marginal cost. Let firm 2 be the big firm, that is, $c_{1} \geq c_{2}$. Further, let $c_{2}=0$ by appropriate normalization. Straightforward but somewhat tedious calculations show that full indigenisation of firms is still an equilibrium provided that $c_{1} \in[0,1 / 3]$. This shows that even major cost differences do not change the main result in this paper. Note also that a cost difference that is even bigger typically leads to corner solutions. For instance, if $c_{1}>1 / 3$ and both firms are indigenised, the small firm 1 produces zero output and makes zero profit in the continuation game with strategic trade policies.

Another assumption that deserves some discussion is that of Cournot competition for which the firms' choice variables are strategic substitutes. As is known from Eaton and Grossman (1986), Bertrand competition, where actions are strategic complements, can lead to strategic trade taxes. Firms may then want to reduce their governments' incentives to use such taxes against them, and international portfolio diversification could be a means for achieving this goal. The crucial question therefore is whether firms' choice variables are indeed strategic substitutes as assumed here. As has been argued by Kreps and Scheinkman (1983), this can be the case even if firms compete in prices at some later stage of the game, if they first make capacity choices. Similarly, strategic substitutability can be caused if firms compete in R\&D contests prior to a price or quantity game. A more general set-up that also lends some support to the case of strategic substitutability and strategic trade subsidies for a wide parameter range is provided by Maggi (1996).

As mentioned in the introduction our results may contribute to explaining 
the well-documentated home-country bias for public firms ${ }^{4}$ and, as private firms might have better control over the international composition of equity why public firms decide to go private again. A few hypotheses that could be tested are as follows:

- As private firms and public firms with large shareholders can more easily control the international composition of ownership of the firm, private firms should be owned domestically to a larger extent than public firms, and the share of international ownership in domestic firms should be larger if the domestic ownership is more dispersed.

- We considered Cournot competition in which a country's strategic trade policy benefits the firms that are located in this country. This reverses with Bertrand competition, and, therefore, the predictions this paper makes on the home bias in international portfolio composition hold for the case of Cournot markets.

- Considering the general equilibrium aspects of strategic trade policy, strategic trade policy focusses on markets with much market power. Hence, the home bias in international portfolio composition should be particularly strong in firms with few Cournot competitors.

- Improved international arrangements to detect and ban strategic trade policy also remove the indigenization incentives that may be caused by

\footnotetext{
${ }^{4}$ Gordon and Bovenberg (1996) survey and disqualify some of the competing explainations, such as high transaction cost of trading foreign securities, exchange rate risks, specific risk correlations between non-traded and traded assets, and contribute an adverse selection explanation, according to which foreigners' lack of knowledge can result also in a less efficient use of real resources. Their explanation and the explanation given here are, of course, not mutually exclusive.
} 
strategic trade policy. Accordingly, trade liberalization should go along with a reduction in the home bias in international firm ownership.

\section{Appendix}

In this appendix we derive equations (8) and (9). Using $\varepsilon=\sum_{h \neq i} \alpha_{h}^{i}$ and $\varepsilon^{h}=\alpha_{h}^{i}$ we can rewrite (6) as

$$
S=-\frac{2 \varepsilon^{h}+2 \varepsilon^{h} s_{i} n+2 \varepsilon^{h} s_{i}+1+s_{h} n+s_{h}-n}{-2 \varepsilon^{h}-1+n}
$$

and (7) as

$$
S=\frac{1+s_{i} n+s_{i}+2 \varepsilon s_{i} n-n+2 \varepsilon n+2 s_{i} \varepsilon n^{2}}{1-n+2 \varepsilon n}
$$

Equating the two right-hand sides and solving for $s^{h}$ we get

$$
s_{h}=-\left(2 \varepsilon n^{2}-2 \varepsilon^{h} n+n-2 \varepsilon n-1\right) \frac{s_{i}}{1-n+2 \varepsilon n}
$$

Using the definition of $S$ we can write

$$
\begin{aligned}
S & =s_{i}-\sum_{h \neq j}\left(2 \varepsilon n^{2}-2 \varepsilon^{h} n+n-2 \varepsilon n-1\right) \frac{s_{i}}{1-n+2 \varepsilon n} \\
& =s_{i}-(n-1)\left(2 \varepsilon n^{2}+n-2 \varepsilon n-1\right) \frac{s_{i}}{1-n+2 \varepsilon n}+\frac{2 n s_{i}}{1-n+2 \varepsilon n} \sum_{h \neq j} \varepsilon^{h} \\
& =s_{i}-(n-1)\left(2 \varepsilon n^{2}+n-2 \varepsilon n-1\right) \frac{s_{i}}{1-n+2 \varepsilon n}+\frac{2 n s_{i}}{1-n+2 \varepsilon n} \varepsilon \\
& =-s_{i} n \frac{-1-2 \varepsilon+2 \varepsilon n^{2}+n-4 \varepsilon n}{1-n+2 \varepsilon n}
\end{aligned}
$$

Substituting back into the first-order condition (7) we get

$$
s_{i}=\frac{n-1-2 \varepsilon n}{2 \varepsilon n^{3}-2 \varepsilon n^{2}+n^{2}+1}
$$

and

$$
S=n \frac{2 \varepsilon n^{2}+n-4 \varepsilon n-1-2 \varepsilon}{2 \varepsilon n^{3}-2 \varepsilon n^{2}+n^{2}+1} .
$$




\section{References}

[1] Adler, M., Dumas B., 1983, International portfolio choice and corporation finance, a synthesis. Journal of Finance 38, 925-984.

[2] Barros, P.P., Cabral L., 1994, Merger policy in open economies. European Economic Review, 38, 1041-1055.

[3] Brander, J.A., Spencer B.J., 1985, Export subsidies and international market share rivalry. Journal of International Economics 18, 83-91.

[4] Dick, A.R., 1993, Strategic trade policy and welfare: The empirical consequences of cross-owenership. Journal of International Economics $35,227-249$.

[5] Eaton, J., Grossman G.M., 1986, Optimal trade and industrial policy under oligopoly. Quarterly Journal of Economics 51(2), 383-406.

[6] Feeney, J., Hillman A.L., 2001, Privatization and the political economy of strategic trade. International Economic Review 42, 535-556.

[7] French, K.R., Poterba J.M., 1991, Investor diversification and international equity markets. NBER Working Paper no. 3609.

[8] Gordon, R.H., Bovenberg L., 1996, Why is capital so immobile internationally? Possible explanations and implications for capital income taxation. American Economic Review 86, 1057-1075.

[9] Konrad, K.A., Lommerud K.E., 2001, Foreign direct investment, intrafirm trade and ownership structure. European Economic Review 45, 475494. 
[10] Kreps, D., Scheinkman J.A., 1983, Quantity precommitment and Bertrand competition yield Cournot outcomes. Bell Journal of Economics 14(2), 326-337.

[11] Maggi, G., 1996, Strategic trade policies with endogenous mode of competition. American Economic Review 86, 237-258.

[12] Tesar, L.L., Werner I.M., 1995, Home bias and high turnover. Journal of International Money and Finance 14, 467-92.

[13] Welzel, P., 1995, Strategic trade policy with internationally owned firms. Bulletin of Economic Research 47, 221-232. 